Rapp. Gronlands geol. Unders. 58, 37-42 (1973)

\title{
PRELIMINARY REPORT ON THE MAPPING OF THE BASALTS OF THE INNER PART OF SCORESBY SUND
}

\author{
W. Stuart Watt and Margrethe Watt
}

\section{Introduction}

The mapping of the basalts was completed during the 1972 field season. The area covered was a large part of southern Gaseland together with the area south of Gåsefjord in the region west of Kap Stevenson as far south as the ice cap. Thirtyseven traverses covering all parts of the basalts succession (totalling about 18000 $\mathrm{m}$ ) form the basis of the interpretation of the regional geology. The sections were linked by helicopter reconnaissance.

A one-day visit was made to Gronau Nunatakker and the western side of Christian IV Gletscher (75 km south-west of the head of Gasefjord) in order to obtain a general idea of the southern inland continuation of the plateau basalts.

\section{Structure af the area}

The basalt sequence is thickest in the south and thins to the north and west. The basalts have overridden a pre-basaltic surface with marked topographic features consisting of steep-sided valleys and gorges cut into the gneisses. The steep prebasaltic topography is mainly concentrated in an arc running from south-eastern Milne Land, across the eastern end of Gåseland to the basement outcrop area on the south side of Gåsefjord and from here following the southern inner part of Gåsefjord continuing further west of the head of Gåsefjord. To the north of this curvilinear belt the pre-basaltic topography forms a gently undulating surface; to the south-east the base of the basalts lies below sea level. On Milne Land and eastern Gåseland rolled quartzitic boulders are frequently found in the bottoms of these gorges. These valleys and gorges were cut after the deposition of the Lower Cretaceous Hartz Fjeld Sandstone (Håkansson et al., 1971) in eastern Milne Land as the basalts have come to lie directly on Jurassic sandstones and shales at a lower topographic level than where the Hartz Fjeld Sandstone is exposed.

The basalts have a regional south-easterly dip of one to two degrees over the whole area. 


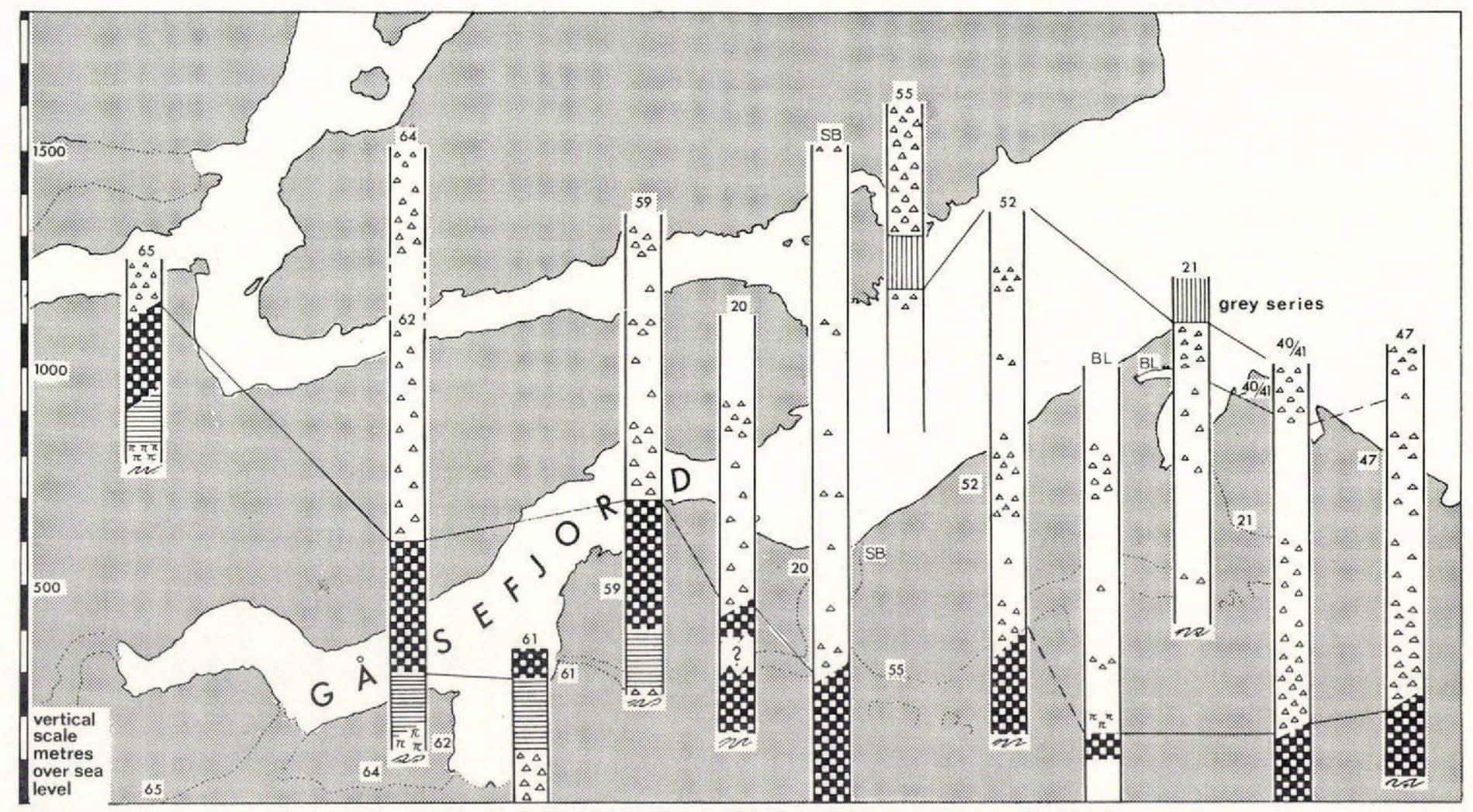

Fig. 4. Schematic basalt profiles south of Gåsefjord. Legend as on fig. 5 . 


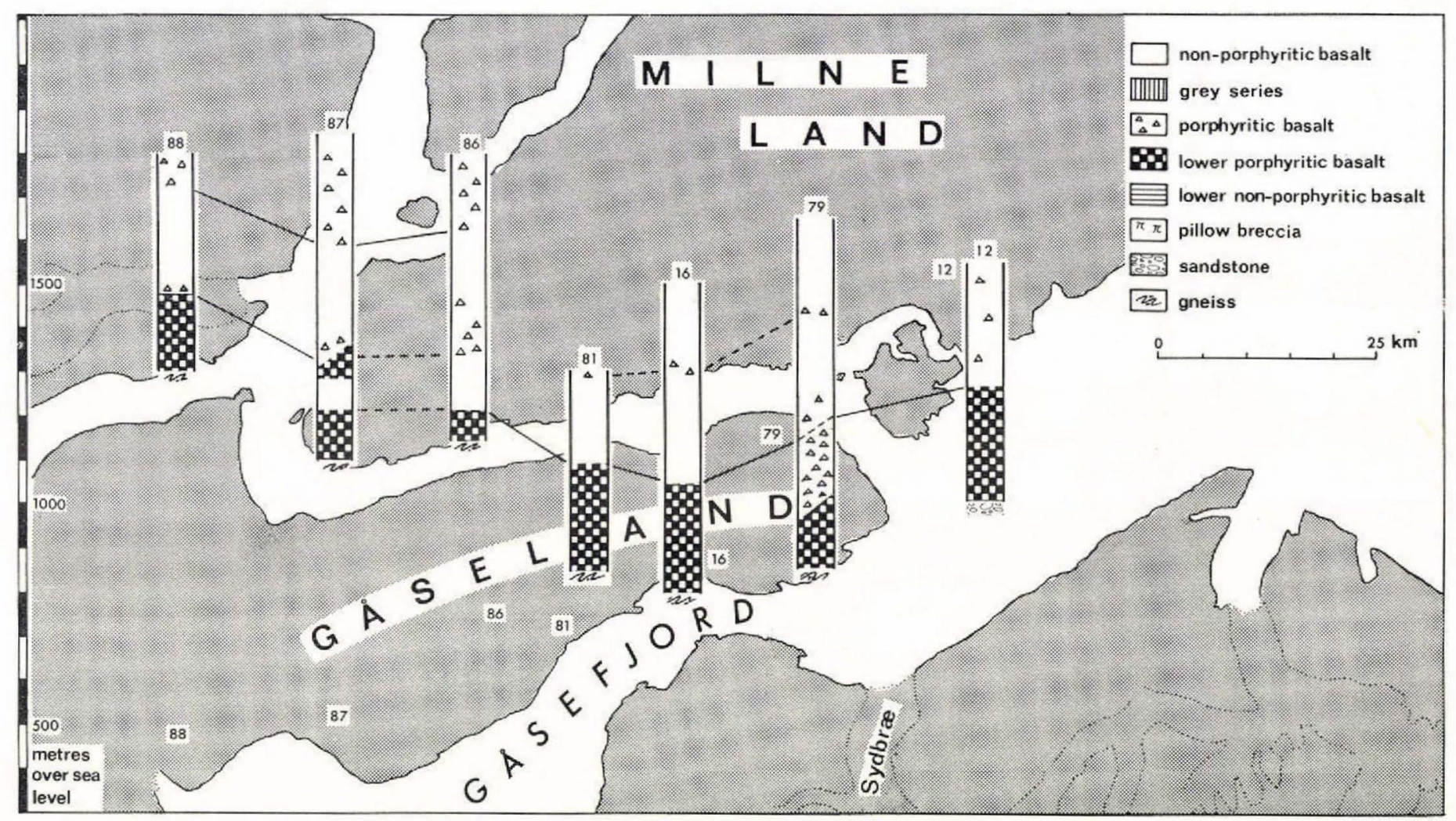

Fig. 5. Schematic basalt profiles on Gåseland and Milne Land. 
Faulting of the basalts is rare. Displacements may reach $50 \mathrm{~m}$ but they are all local and in several directions. On Gåseland $\mathrm{N}-\mathrm{S}$ trending lineaments can be traced over several ridges but no displacements are visible along these features; they could well be comparable to the similar features observed east of Kap Stevenson.

Landslipping is common in places and certain poorly exposed 'faults' may in practice be landslipped masses. On both sides of the large east-west valley in eastern Gåseland landslipped masses are frequent, the slide planes being mostly parallel to the valley and the basalts dropping into the valley. Landslipping is also prominent along the north side of inner Gassefjord. It is mainly confined to areas where basalt flows overlie irregular pre-basaltic topography or sediments.

\section{Stratigraphic division of the basalts}

On the eastern tip of Gåseland and on eastern Milne Land the basalt succession overlies the Charcot Bugt Sandstone, which has been ascribed an Oxfordian age; elsewhere it overlies gneisses. In the areas of steep pre-basaltic topography pillow breccias are frequently found at the base of the sequence filling the bottom of the gorges, mostly associated with the lowermost flows below the level of the pre-basaltic hill tops. The position of the pillow breccia is therefore considered to have little stratigraphic significance.

From the structure of the area the lowest flows are considered to be those immediately overlying the gneisses near sea level on the southern side of Gåsefjord (fig. 4). Here there is a thin sequence of slightly porphyritic flows. These basal flows are only present at a couple of localities as to the south this stratigraphic level drops below sea level (fig. 4, profiles 59 \& 61).

The basal porphyritic flows are overlain by about $150 \mathrm{~m}$ of comparatively thin, non-porphyritic basalt flows up to $15 \mathrm{~m}$ in thickness as well as numerous, thin flow units. These flow units frequently overlie variable thicknesses of pillow breccia which form the local base of the succession and are intercalated with them.

Above the non-porphyritic flows is a group of flows of $300 \mathrm{~m}$ thickness characterised by clusters of plagioclase phenocrysts, commonly stellate, up to $10 \mathrm{~mm}$ across (rarely as large as $40 \mathrm{~mm}$ ). These are probably the same group of flows that are characteristically at the base of the succession on southern and eastern Gaseland and southern Milne Land (figs $4 \& 5$ ). The individual flows are up to $50 \mathrm{~m}$ in thickness at the base of the group decreasing in thickness higher in the succession. Higher in the succession the phenocrysts of these flows decrease in size and density. In the region centred on Sydbræ the phenocrysts rapidly disappear upwards to give a thick sequence of about $800 \mathrm{~m}$ with only rare phenocrysts. This 
non-porphyritic group of flows becomes diffuse to the east and west in that porphyritic and non-porphyritic flows alternate.

Above the mainly non-porphyritic sequence of flows is a thin sequence of flows up to about $100 \mathrm{~m}$ in thickness composed of numerous flow units. The units are often only from $50 \mathrm{~cm}$ upwards in thickness and occasionally as little as $3 \mathrm{~cm}$, frequently showing prominent ropy tops. These flows are frequently heavily impregnated with zeolitic material which partly replaces the plagioclase as well as forming most of the groundmass, and gives the basalt a coarser grained appearance; these features having the effect of giving the whole unit a grey appearance, wherefore it has been referred to as the 'grey series'. Vertical vesicular pipes are common in the more massive parts of these flow units. This group of flow units forms a prominent marker horizon in the area east of Sydbræ.

Overlying this grey series of flow units the flows are again markedly porphyritic with numerous $(7 \%) 3$ to $6 \mathrm{~mm}$ clusters of plagioclase phenocrysts sometimes with associated pyroxene phenocrysts. The same sequence of flows, together with the underlying grey series of flow units is present on Skrænterne to the east where it was investigated during the 1971 field season (Watt et al., 1972).

\section{Amygdale minerals}

The amygdale minerals in the vesicular parts of the flows and in the few amygdales in the massive parts of the flow appear to follow the same pattern of occurrence as was noted in previous years. Reniform haematite appears as an amygdale mineral only in the flows north-west of the head of Gåsefjord; it is not associated with any other mineral in the amygdales.

\section{Dykes}

Basic dykes are present in the western part of the area and around Sydbræ but are practically unknown elsewhere. Practically all the dykes seen cut completely through the basalt succession. However, near Magga Dan Gletscher in the south a dyke appears to have been a feeder to a flow as it fans out at a particular level and does not continue higher in the succession. The continuation of this dyke to the west is seen to cut the lower basalts to about the same height.

Dykes in the area between Sydbræ and Magga Dan Gletscher are prominent in two directions approximately trending E-W and NNW-SSE. They are all doleritic and may be up to $15 \mathrm{~m}$ in width.

The area south of the innermost part of Gåsefjord has the greatest dyke density 
in the whole basalt region (apart from the swarm parallel to the Blosseville Kyst). Here NNW-SSE dykes are partly lamprophyric and partly doleritic. The doleritic dykes are up to $50 \mathrm{~m}$ in width, and have trends of N-S in the west to NE-SW in Hjørnedal. These dykes appear to form a radiating pattern as described by Wenk (1961). The E-W trending dykes at Sydbra could also fit this radiating pattern.

\section{References}

Håkansson, E., Birkelund, T., Heinberg, C. \& Willumsen, P. 1971: Preliminary results of mapping the Upper Jurassic and Lower Cretaceous sediments of Milne Land. Rapp. Gronlands geol. Unders. 37, 32-41.

Watt, W. S., Emeleus, C. H. \& Watt, M. 1972: Preliminary report on the basalts of Volquart Boons Kyst, East Greenland. Rapp. Gronlands geol. Unders. 48, 75-83.

Wenk, E. 1961: On the crystalline basement and the basal part of the pre-Cambrian Eleonore Bay group in the southwestern part of Scoresby Sund. Meddr Gronland 168(1). 